\title{
隆起性皮膚線維肉腫
}

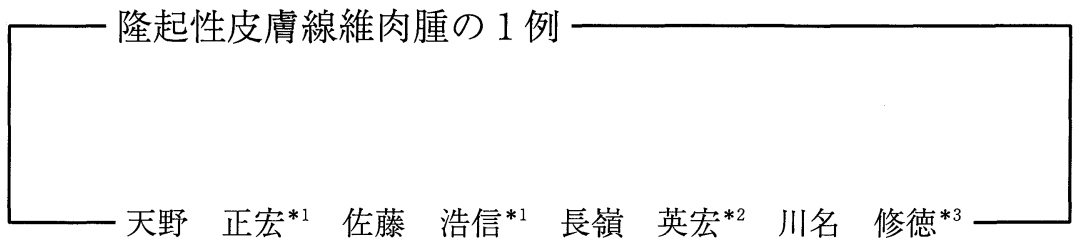

\section{A case of dermatofibrosarcoma protuberans}

Masahiro AMANO, Hironobu SATOH, Hidehiro NAGAMINE, Osanori KAWANA

Summary : Dermatofibrosarcoma protuberans (DFSP) tends to relapse locally if the tumor had not be removed totally.

We report a 57-year-old male with a DFSP on the left inguinal lesion. At 48 years the tumor was removed marginally and misdiagnosed as keoid by histological examinations. 9 years later it recurred under the surgical scar on the same lesion. He had a mental retardation and didn't notice it. Wide excision of the lesion including fascia and skin grafting were perfomed. Histopathologicaly the tumor was composed of uniform spindle-shaped fibroblast-like cells with mild atypia and arranged in a storiform pattern. No recurrece or distant metastasis was seen under the follow up period of 2 years. [Skin Cancer (Japan) 2000 ; $15: 35-38$ ]

Key words : Dermatofibrosarcoma protuberans, Relapse, Mohs micrographic surgery

\section{はじめに}

隆起性皮膚線維肉腫 (以下 DFSP と略す) は, 不完全な外科手術を行うと局所再発を繰り返 し，遠隔転移を生じることもある。今回，初回 病理診断を瘏痕ケロイドと䛊診し, 精神発達遅 滞があり，社会福祉施設入園中で発見が遅れ， 約 9 年後に再発を認めたDFSP の 1 例を報告す る。

\footnotetext{
${ }^{* 1}$ 宮崎県立延岡病院皮虐科

*2 宮崎県立宮崎病院皮虐科

*3 延岡市
}

\section{症例}

患 者: 57 歳, 男性

初 診：昭和 62 年 7 月 9 日

既往歴: 10 歳頃, 䯣膜炎罹患後精神発達遅滞 を認め, 40 歳頃より社会福祉施設に入園中であ る。

家族歴：特記すべきことなし。

現病歴: 28 歳時, 左鼠径部の皮膚腫瘤切除を 行ったが，良性だったという（詳細は不明）。48 歳時, 同部の手術瘕痕辺縁に腫瘤ができ膨隆し てきたため，当科を初診した。昭和 62 年 8 月 25 日, 腫瘍辺縁ぎりぎりにて切除し（一回目手 
術)。瘀痕ケロイドと病理組織診断した。

現 症: 左鼠径部に28 歳時の皮膚腫瘤手術 㓔痕があり，その㓔痕部辺縁より発生した母指 頭大の赤色隆起した腫瘤を認める（図１）。

入院時検査所見: 入院時末梢血, 生化学, 尿, 胸部 X線像，心電図など一般検査所見は正常 で, 胸腹部 CT 検査でも, 所属リンパ節, 遠隔 臟器への転移は認めなかった。

治療および経過：当科での一回目の手術より 約 9 年が経過した 57 歳時, 同部に痛みを訴え, 平成 8 年 10 月 22 日当科を再診した。左鼠径部 の手術症痕直下に $3 \times 2.5 \mathrm{~cm}$ 大の皮下腫瘤を認 娼 2 )。12 月 12 日, 左鼠径部の手術痏痕

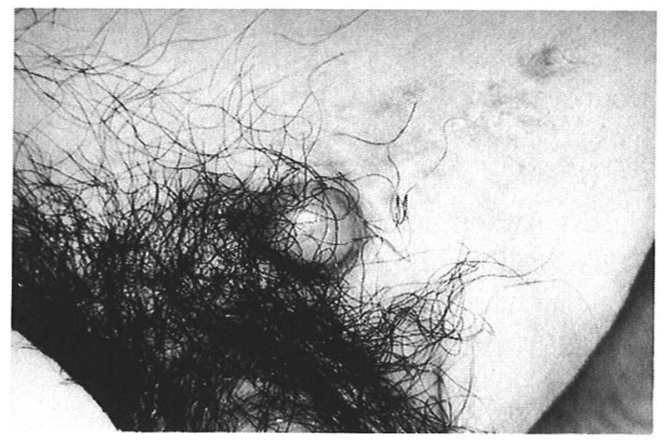

図 1．初診時臨床像

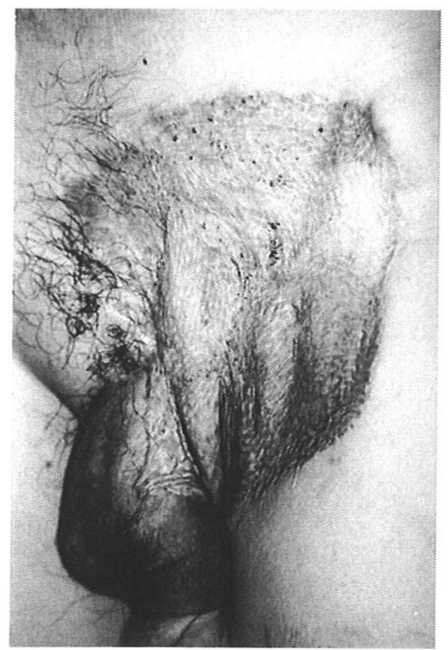

図 3. 最近の臨床像
および皮下腫瘤を含め切除縫縮した（二回目手 術)。病理組織診断はDFSPであり, 辺縁に腫瘍 細胞の残存があり, 平成 9 年 1 月 9 日, 切除縁 を $3 \mathrm{~cm}$ とり, 下床は筋膜をつけて切除, 分層植 皮術を行った(三回目手術)。しかし切除組織標 本辺縁に腫湯細胞が確認されたため, 平成 9 年 4 月 29 日, 切除縁をさらに $5 \mathrm{~cm}$ とり,下床は筋 膜をつけて切除し分層植皮術を行った（四回目 手術)。病理組織学的には腫瘍細胞の残存はな く, 術後 2 年を経過するも再発転移を認めない (図 3 )。

病理組織学的所見：肉眼所見では, 病巣と辺 縁組織との境界は明瞭そうである(図 4 )。しか

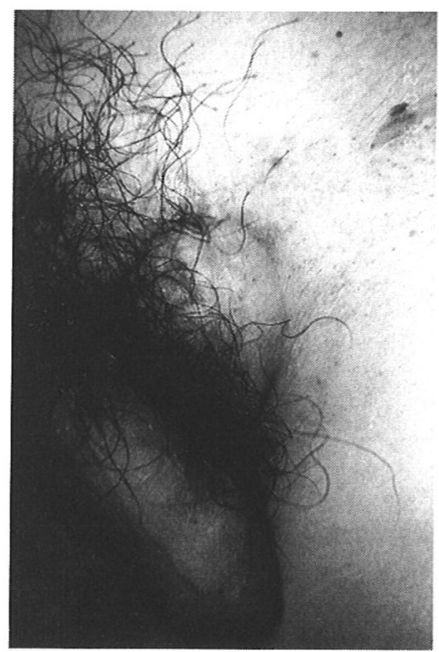

図 2. 2 回目手術前

左鼠径部に $2.5 \times 3 \mathrm{~cm}$ 大の皮下腫瘤を認める

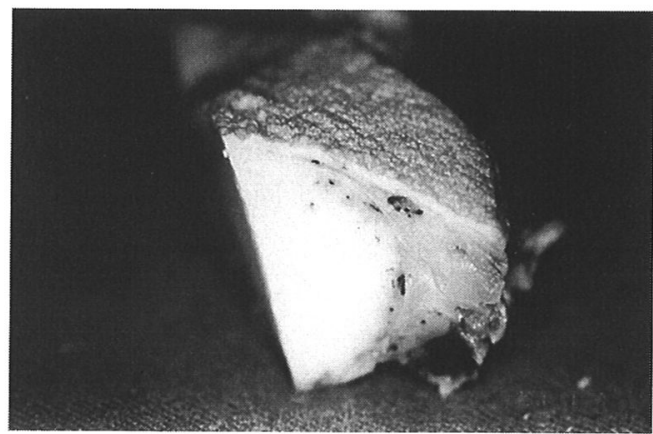

図 4.2 回目手術後標本 病巣と辺縁組織との境界は明暸そうである 


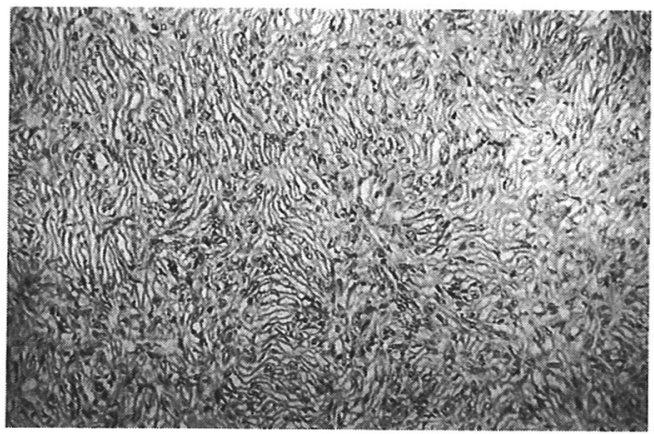

図 5.疲缯病理組織像

a. storiform pattern像を呈す (H.E.染色 弱拡大像)

b. 軽度異型性を伴う線維芽細胞様細胞よりなる (H.E. 染色 強拡大像)

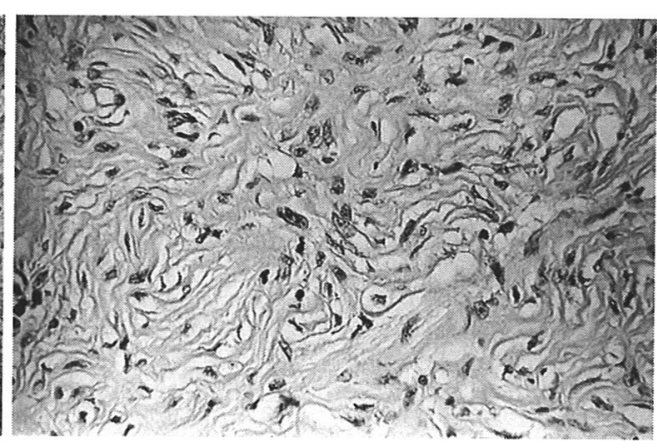

$a \mid b$
し組織学的には，真皮上層より皮下組織にかけ て被膜形成はなく増殖細胞の浸潤を認めた。被 覆表皮は萎縮していた。増殖細胞は storiform pattern を呈し，紡錘形から楕円形からなる核 をもつ線維芽細胞様細胞からなり，核の異型性 は軽度から中等度で，核分裂像は少ない（図 5 )。腫瘍細胞は, 辺縁, 下床の線維性隔壁に 沿って予想以上に広く深く浸潤している。

\section{考察}

DFSP は，Darier と Ferrand ${ }^{1)}$ が，増殖かつ 再発する皮膚線維腫として初めて記載された。 Eiginger $~^{2)}$ は，DFSP を軟部組織腫瘍のなか で fibroushistiocytic tumor と位置付け, 悪性度 に扔いて局所浸潤性があり局所再発は多いが, 遠隔転位はまれであることから，中間群に分類 した。しかし，局所再発を繰り返すうちに遠隔 転移もありうると指摘している。

\section{1. 診断について}

皮膚表面より隆起する赤色から正常皮膚色の 腫瘤で，短時間に増大し径 $10 \mathrm{~cm}$ を超えたもの もあるが，大多数の症例は緩徐である。鑑別診 断すべきは, 初期病変では㓔痕組織やモルフェ ア，やや進行したものは皮膚線維腫（DF），さ らに進行した病変では，悪性線維性組織球腫 $(\mathrm{MFH})$ や線維肉腫が挙げられる ${ }^{3)}$ 。

本症の病理組織学的像の特徵は, 紡錘形から
楕円形からなる核をもつ線維芽細胞様細胞が一 定の方向を示し花むしろに似ているため storiform pattern と表現される。核の異型性は 軽度から中等度で，核分裂像は多くはないこと である。DFや MFH など線維性組織球系腫瘍と の鑑別が大切である。Kamino H ら ${ }^{4)}$ は, DF と 比較して DFSP では皮下組織への浸潤パターン が honeycomb または lace like pattern をとるも の $(60 \%)$ ，表皮に平行に multilayered pattern を呈するもの (30\%)，その混在 (10\%) である。 これに対して MFH は，核の異型性が強く核分 裂像が多く認められるが, DFSP とは鑑別困難 なことが多い。Aiba ら ${ }^{5)}$ は DFSP ではCD34を ほほ全例に陽性所見を得, MFH と鑑別可能と し, 多田ら ${ }^{6)}$ はこの CD34 を用いて DFSP の腫 瘍浸潤の範囲の同定に有用であったと報告して いる。

\section{2. 治療について}

DFSP 治療の第一選択は，全摘出である。化 学療法や放射線療法有効例の報告はない。

手術法は軟部悪性腫瘍に準じて, 下床は解剖 学的バリアーをつけて摘出することには異論は ない。しかし，切除範囲の決定について今な㧈 標準指針はない。Hobbs ら ${ }^{7)}$ は, Mohs micrographic surgery（以下，MMS法）を用いて DFSP の治療に有用であったと報告している。 MMS 法は, DFSP 腫瘍辺縁ぎりぎりで切除し, 標本をさしみ切りにして水平方向の切除標本を 
作り, 術中迅速診断を行い, 術中に詳細な腫瘍 浸潤のマッピングを行う方法である。さらに腫 瘍細胞陽性部分を再切除して，辺縁に腫瘍細胞 がなくなるまで再切除を続ける。Haycox ら ${ }^{8)}$ は，DFSPに抢いて今までの $3 \mathrm{~cm}$ wide local excision 法の再発率が $11 \%$ に対して, MMS 法 は $2.4 \%$ であったと報告している。また，CD34 を用いたMMS 法により surgical margin に適用 した Jimenez ら の) の報告もある。この方法を用 いて Parker ら ${ }^{10)}$ は DFSP 計 20 例 (primary 12 例, recurrent 8 例) の切除 margin は, 腫瘍の 大きさや再発の有無にかかわらず $2.5 \mathrm{~cm}$ で十分 であると報告した。自験例では 3 回目手術病理 標本において腫瘍辺縁より $3 \mathrm{~cm}$ 離れたところ に, 腫瘍細胞を認めた。切除縁は何 $\mathrm{cm}$ あれば 十分ということではなく, 個々の症例で決定す べきである。竹村らは ${ }^{11)}$, MMS 法を行うには, 習熟した皮膚科医, 病理医, 術者およびその チームワークが必要で, 現在の本邦の医療状況 では，すべての DFSP に対してこの方法を行う ことは困難であると述べている。

我々の施設では, 図 6 の如く術中迅速標本に て残存の疑われる部位を $5 \sim 10$ 力所提出し,さ らに切除標本にて $5 \sim 10$ カ所切り出しを行い, 腫瘍細胞の残存の有無を確認している。術中迅 速診断では, 腫瘍細胞残存がなっかった部位に 病理組織標本では存在することがある。MMS 法に比較すると不完全であるが, 我々の様な中

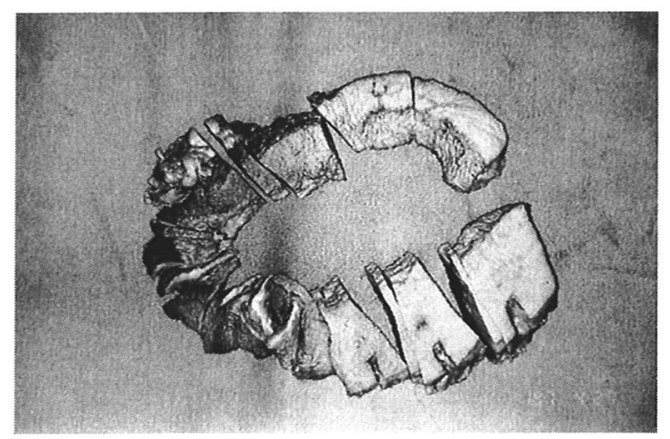

図6.4 回目手術後標本

術中迅速標本を提出した後, 10 カ所病理標本 を切り出し, 腫瘍の残存の有無を確認した
小病院（皮䖉科医二人, 病理医一人）において も，ある程度の腫瘍の浸潤のマッピングが可能 である。

\section{文献}

1) Enzinger, F. M., Weiss, S. W. : SOFT TISSUE TUMORS. Third edition, Mosby-Year Book, Inc., St. Louis, 1995, pp. 252-262.

2) Enzinger, F. M., Weiss, S. W. : SOFT TISSUE TUMORS. Third edition, Mosby-Year Book, Inc., St. Louis, 1995, pp. 6-8.

3) Fish, F. S.: Soft Tissue Sarcomas in Dermatology. Dermatol. Surg., 22 : 268-273, 1996.

4) Kamino, H., Jacobson, M. : Dermatofibroma Extending into the Subcutaneous Tissue. Am. J .Surg. Pathol., 14 : 1156-1164, 1990.

5) Aiba, S., Tabata, N., Ishii, H., et al. : Dermatofibrosarcoma protuberans is a unique fibrohistiocytic tumor expressing CD34. Br. J. Dermatol., 127: 79-84, 1992.

6 ）多田弥生, 湧川基史, 中村晃一郎, 他: 隆起性皮 周線維肉腫の 1 例。臨皮, 52:798-800, 1998.

7) Hobbs, E. R., Wheeland, R. G., Bailin, P. L., et al. : Treatment of Dermatofibrosarcoma Protuberans with Mohs Micrographic Surgery. Ann. Surg., 207 : 102-107, 1988.

8) Haycox, C. L., Odland, P. B., Olbricht, S. M., et al. : Dermatofibrosarcoma Protuberans (DFSP) : Growth Characteristics Based on Tumor Modeling and a Review of Cases Treated with Mohs Micrographic Surgery. Ann. Plast. Surg., 38 : 246251, 1997.

9) Jimenez, F. J., Grichnik, J. M., Buchnan, M. D., et al. : Immunohistochemical Margin Control Applied to Mohs Micrographic Surgical Excision of Dermatofibrosarcoma Protuberans. J. Dermatol. Surg. Oncol., $20: 687-689,1994$.

10) Parker, T. L., Zitelli, J. A. : Surgical margins for excision of dermatofibrosarcoma protuberans. J. Am. Acad. Dermatol., 3 : 233-236, 1995.

11）竹村卓也, 神保好夫, 加藤武男, 他 : 右腰部に発 生した巨大隆起性皮膚線維肉腫の 1 例. 皮虐臨 床, 41:155-159, 1999. 